\title{
WUJUD DAN MAKNA PRAGMATIK BAHASA NONVERBAL DALAM KOMUNIKASI MASYARAKAT JAWA: KAJIAN ETNOPRAGMATIK
}

\author{
Pranowo $^{1} \quad$ Neneng Tiya Ati Yanti ${ }^{2}$ \\ Universitas Sanata Dharma ${ }^{1,2}$ \\ prof.pranowo2@gmail.com ${ }^{1}$
}

\begin{abstract}
Abstrak
Tidak semua gerakan nonverbal dapat disebut bahasa nonverbal. Gerakan yang disebut bahasa nonverbal adalah gerakan yang digunakan untuk mengungkapkan makna pragmatik penutur. Bahasa nonverbal dibedakan menjadi dua yaitu dinamis dan statis (Hu, 2014). Data dikumpulkan melalui wawancara dengan narasumber, dan observasi pengalaman hidup sehari-hari sebagai bagian dari warga masyarakat Jawa. Data yang ditemukan kemudian dideskripsikan berdasarkan wujud dan makna pragmatik pemakaian bahasa nonverbal dalam komunikasi. Hasil kajian yang ditemukan adalah wujud bahasa nonverbal dinamis berupa gerakan kepala, gerakan tangan dan bagianbagiannya (gelengan/anggukan kepala, lambaian tangan, kerlingan mata, kerdipan mata, gerakan pundak, dsb.). Wujud bahasa nonverbal statis ada dua, yaitu yang berkaitan dengan (a) tubuh (postur tubuh, warna kulit, warna rabut), dan (b) status sosial, yang meliputi asal keturunan (priyayi alit dan priyayi luhur), tingkat kekayaan (kukila, turangga, wanudya), tingkat intelektual (esem bupati, senyum mantri, dan dhupak bujang), cara memilih jodoh (bobot, bibit, dan bebet). Temuan hasil penelitian makna pragmatik meliputi (a) pengulangan tuturan verbal, (b) penggantian tuturan verbal, (c) mempertentangkan, (d) melengkapi tuturan, dan (e) memberi penekanan.
\end{abstract}

Kata kunci: bahasa nonverbal, etnopragmatik, wujud, makna pragmatik

\begin{abstract}
Not all nonverbal movements can be categorized as a nonverbal language. A movement is called nonverbal language if it is used to express the pragmatic meaning of the speaker. Nonverbal languages can be divided into two, namely dynamic and static ( $\mathrm{Hu}, 2014)$. Data was collected through interviews with informants and observations of daily life experiences as part of the Javanese community. The data found is then described based on the form and pragmatic meaning of the use of nonverbal language in communication. The result of this study shows that dynamic nonverbal language can be found in the form of head movements, hand movements and parts (head shake, nodding, hand waving, eye twitching, eye blinking, shoulder movements, etc.). There are two types of static nonverbal language forms, namely (a) relating to the body (body posture, skin color, rabut color), and (b) relating to social status, including hereditary origin (priyayi alit and noble priyayi), wealth level (kukila 'birds', turangga 'horses', wanudya 'women'), intellectual level (regent element, mantri smile, and bachelor soccer), how to choose a mate (weight 'bobot', seeds "bibit", wealth "bèbèt"). The findings on the pragmatic meaning include (a) repetition of verbal speech, (b) replacement of verbal speech, (c) contrasting, (d) completing speech, and (e) giving emphasis.
\end{abstract}

Keywords: nonverbal language, ethnopragmatic, form, pragmatic meaning 


\section{PENDAHULUAN}

Bahasa verbal merupakan bahasa yang diungkapkan menggunakan kata-kata yang membentuk tuturan, sedangkan bahasa nonverbal adalah bahasa yang diungkapkan menggunakan aspek nonlinguistik untuk menyampaikan pesan penutur, seperti mata (kerlingan mata, kerdipan mata), gerakan kepala (anggukan atau gelengan kepala), gerakan anggota badan (gerakan tangan, gerakan badan), ekspresi wajah, dan lain-lain (Lapakko, 2007; Bonaccio, O'Reilly, O'Sullivan, \& Chiocchio, 2016). Kedua jenis bahasa di atas menunjukkan bahwa bahasa verbal maupun nonverbal dibutuhkan oleh manusia dalam berkomunikasi (Knapp \& Hall, 2002).

Selama ini, ketika orang berkomunikasi lisan selalu hanya memperhatikan bahasa verbal, padahal pemakaian bahasa verbal lisan kadang-kadang masih menimbulkan ketidakjelasan. Kejelasan baru dapat diketahui setelah disertai konteks dan salah satu konteksnya adalah bahasa nonverbal. Ada tiga macam makna pragmatik bahasa nonverbal, yaitu ada yang berdiri sendiri, ada yang menjadi konteks bahasa verbal lisan, serta ada makna pragmatik metaforis yang menggambarkan status sosial seseorang dalam masyarakat (Pranowo, 2018).

Bahasa nonverbal yang berdiri sendiri ketika seseorang berkomunikasi tidak menggunakan kata, tetapi menggunakan gestur, isyarat, tanda, simbol, gerak, tatapan mata, gelengan atau anggukan kepala, dsb. Jika komunikasi terjadi seperti itu, bahasa nonverbal memang menjadi alat utama dalam komunikasi, seperti anak kecil yang belum dapat berbahasa verbal, atau dua orang yang berkomunikasi tetapi satu sama lain tidak menguasai masingmasing bahasa verbalnya.

Sementara itu, bahasa nonverbal yang berfungsi menjadi konteks akan dapat meniadakan multitafsir suatu tuturan, seperti tuturan "Yona orangnya terbuka". Tuturan itu jika ada konteks linguistik "saya suka berteman dengan dia" akan berbeda makna pragmatiknya jika konteks linguistiknya "saya tidak suka berbicara hal-hal yang bersifat rahasia dengannya".

Semua etnis di Indonesia memiliki latar belakang budaya yang berbeda-beda. Ketika berjabat tangan, orang Jawa selalu menjulurkan telapak tangan terlebih dahulu, baru kemudian menempelkan telapak tangan ke pelipis. Sementara itu, etnis Sunda ketika berjabat tangan mengawali dengan menempelkan kedua telapak tangan ke bibir, kemudian menjabat tangan mitra tutur. Hal seperti itu dengan berbagai variasinya setiap etnis memiliki budaya berbahasa nonverbal sendiri-sendiri. Hal sepeti itu selaras dengan pendapat Spradley (1979) bahwa berbahasa merupakan perilaku bahasa. Bahasa nonverbal termasuk perilaku bahasa.

Bahasa nonverbal yang berupa makna pragmatik metaforis dapat menggambarkan status sosial seseorang, seperti kedudukan dalam masyarakat, asal keturunan, atau jumlah kekayaan. Semua itu menggambarkan bahasa nonverbal (Pranowo, 2018). Hal tersebut menunjukkan bahwa bahasa verbal dan bahasa nonverbal dibutuhkan saat berkomunikasi. Penutur dan mitra tutur membutuhkan peran bahasa nonverbal agar pesan tersampaikan dengan baik.

Bahasa nonverbal yang diteliti adalah percakapan sehari-hari baik bahasa verbal lisan maupun bahasa nonverbal di ruang dosen, di ruang kelas, dan beberapa peristiwa tutur yang terjadi dalam upacara adat perkawinan gaya Yogyakarta. Berdasarkan latar belakang di atas, rumusan masalah utama artikel ini adalah "bagaimanakah wujud dan makna pragmatik bahasa nonverbal dalam komunikasi verbal lisan?". Atas dasar rumusan masalah utama, disusun submasalah sebagai berikut (a) wujud bahasa nonverbal apa sajakah yang terdapat dalam 
komunikasi lisan verbal, dan (b) makna pragmatik apa sajakah yang ingin diungkapkan melalui bahasa verbal dengan dukungan bahasa nonverbal?

\section{KAJIAN PUSTAKA}

\subsection{Bahasa sebagai Alat Komunikasi}

Knapp \& Hall (2002) mengemukakan bahwa komunikasi lisan menggunakan bahasa verbal dan bahasa nonverbal. Komunikasi verbal adalah komunikasi yang menggunakan kata-kata, sedangkan komunikasi nonverbal mengacu pada beberapa cara berkomunikasi selain penggunaan kata-kata. Memang, pemakaian bahasa yang mudah dilihat dan diamati adalah bahasa verbal yang berupa kata-kata atau ujaran. Di samping itu, bahasa nonverbal berupa mimik, gerak gerik tubuh, sikap, atau perilaku yang dapat mendukung pengungkapan makna pragmatik seseorang.

McGraw mengungkapkan bahwa 93\% komponen komunikasi adalah bahasa nonverbal (Lapakko, 2007: 1). Mehrabian (2017: 3) menyatakan bahwa bahasa nonverbal dalam berkomunikasi merupakan fenomena yang kompleks dan berkontribusi besar pada penyampaian pesan. Jika berkomuniksi hanya menggunakan bahasa verbal, pesan yang disampaikan tidak konsisten (tidak selalu dapat dipahami makna pragmatiknya oleh mitra tutur) (Wang, 2014). Berdasarkan teori di atas dapat disimpulkan bahwa bahasa nonverbal berpengaruh besar dalam menyampaikan makna pragmatik. Knapp \& Hall (2002) mengemukakan bahwa komunikasi dengan bahasa nonverbal mengacu pada beberapa cara seperti kontak mata, bahasa tubuh atau isyarat vokal. Miller dan Barry mengemukakan bahwa bahasa nonverbal merupakan semua aspek penyampaian pesan tanpa kata-kata yang dapat diidentifikasi melalui proses komunikasi, seperti gestur, kontak mata, ekpresi wajah (Miller, 2011; Barry, 2011).

Argyle (1972) mempertimbangkan bahwa ada tiga bentuk komunikasi bahasa nonverbal yaitu (1) komunikasi bahasa nonverbal sikap, emosi, manipulasi, dan situasi langsung; (2) komunikasi bahasa nonverbal sebagai pendukung dan pelengkap komunikasi verbal; (3) komunikasi bahasa nonverbal sebagai pengganti bahasa. Berdasarkan tiga bentuk komunikasi di atas, bahasa nonverbal berpengaruh besar terhadap penyampaian makna pragmatik dalam berkomunikasi. Hal tersebut menunjukkan bahwa pada saat berkomunikasi, kontak mata antara penutur dan mitra tutur melalui bahasa nonverbal menjadi aspek penting dalam berkomunikasi untuk menyampaikan makna pragmatik.

\subsection{Konteks dalam Pragmatik}

Levinson (1983) mengemukakan bahwa studi pragmatik adalah studi mengenai pemakaian bahasa berdasarkan konteks. Kajian bahasa nonverbal berdasarkan pendekatan pragmatik di samping menempatkan diri sebagai objek kajian sekaligus juga dapat diposisikan sebagai konteks pemakaian bahasa verbal. Song (2011) mengemukakan bahwa konteks meliputi konteks linguistik (co-teks) dan konteks di luar linguistik, seperti konteks situasi, konteks sosial, konteks societal, dan konteks budaya. Dengan demikian, baik konteks secara linguistik maupun nonlinguistik dapat dipahami sesuai dengan kondisi ketika penutur dan mitra tutur saling bertutur. Secara singkat diuraikan sebagai berikut.

Pertama, konteks situasi bukan hanya latar belakang kata-kata pada saat tertentu, melainkan mencakup pengaturan budaya seluruh ujaran dan sejarah pribadi para peserta. Konteks situasi mencakup faktor linguistik dan nonlinguistik. Faktor linguistik yaitu konteks 
atau ko-teks berupa kalimat yang biasanya mendahului atau mengikuti kalimat atau elemen bahasa lain. Sedangkan konteks nonlinguitik merupakan konteks yang mengacu pada beberapa cara selain penggunaan kata-kata seperti kontak mata, gerakan anggota badan seperti ekspresi wajah, gerakan mata, gerakan kepala, gerakan tangan, gerakan badan, atau kombinasi yang satu dengan yang lain.

Kedua, konteks sosial dan budaya adalah hal-hal yang timbul sebagai akibat dari munculnya interaksi antaranggota masyarakat dalam budaya tertentu. Perhatikan contoh di atas ketika anak-anak Indonesia timur mengatakan "Sapi main bola, Ma". Mereka sebagai bagian masyarakat Flores biasa bertutur dengan cara memotong kata "saya menjadi Sa-", "pergi menjadi pi-“, sehingga klausa "Saya pergi" menjadi "Sapi”. Lain halnya dengan orang Batak. Orang Batak sering mengatakan "Air Bah". Bagi orang di luar orang Batak ucapan "air bah" bermakna "banjir", sementara orang Batak memaknai secara pragmatik "minta minum" (Saya minta air minum, Pak"). Perbedaan makna pragmatik seperti itu perlu dipahami atas dasar konteks sosial budaya masyarakat setempat (makna local wisdom).

Ketiga, konteks sosietal adalah konteks yang menjadi faktor penentu kedudukan seseorang dalam strata sosial masyarakat. Hal ini menunjukkan bahwa munculnya konteks sosietal adalah adanya kekuasaan (power), sedangkan dasar dari kemunculan konteks sosietal itu adalah adanya solidaritas (solidarity) (Rahardi, 2009).

\section{METODE KAJIAN}

Artikel ini menggunakan pendekatan etnopragmatik, sebagai gabungan dari kajian etnografi dan pragmatik. Kajian etnografi pada dasarnya adalah kajian budaya suatu masyarakat. Kajian budaya diklasifikasikan menjadi tiga, yaitu cultural knowledge, cultural behavior, dan cultural artifac (Spradley, Elizabeth, \& Amirudin., 1997). Pemakaian bahasa nonverbal dalam kajian etnografi termasuk kajian perilaku budaya (cultural behavior). Dengan demikian, bahasa nonverbal termasuk bagian dari kajian kebudayaan.

Sementara itu, kajian ini juga menggunakan pendekatan pragmatik sebagai kajian penggunaan bahasa berdasarkan konteks pemakaiannya (Rahardi, 2009). Konteks pemakaian bahasa mencakup konteks linguistik, konteks situasi, konteks sosial, konteks sosietal, dan konteks kultural (Song, 2011). Dengan demikian, kajian etnopragmatik merupakan kajian penggunaan bahasa nonverbal sebagai perilaku budaya dengan memperhatikan konteks pemakaianya.

Pendekatan ini menjadi sangat relevan dan realistis seperti yang dikemukakan oleh Lapakko dan Bonaccio bahwa ketika seseorang berkomunikasi verbal lisan selalu didukung oleh bahasa nonverbal sesuai dengan latar belakang budayanya (Lapakko, 2007). Bahkan dalam komunikasi lisan, bahasa nonverbal mencapai $93 \%$ sementara bahasa verbalnya hanya $7 \%$ (Mehrabian, 2017; Bonaccio et al., 2016).

Teknik pengumpulan data menggunakan teknik observasi, teknik wawancara, dan teknik perekaman. Teknik observasi dilakukan dengan mengadakan pengamatan terhadap berbagai peristiwa tutur yang terjadi di tempat-tempat sumber data. Pengamatan dilakukan melalui pemakaian bahasa verbal lisan beserta bahasa nonverbalnya agar dapat menggambarkan pola komunikasinya. Teknik wawancara dilakukan dengan mengadakan wawancara terhadap informan yang digunakan untuk mengumpulkan data. Teknik wawancara dilakukan untuk menggambarkan alasan pemakaian bahasa nonverbal ketika mereka berkomunikasi. Teknik 
perekaman dilakukan untuk merekam informan yang sedang melakukan komunikasi agar mendapatkan gambar nyata pemakaian bahasa verbal maupun nonverbal dalam setiap peristiwa tutur. Hasil perekaman digunakan untuk mengecek kembali hasil pengumpulan data melalui observasi jika ada data yang tidak teramati sebelumya.

Teknik analisis data dilakukan dengan langkah sebagai berikut. Pertama, peneliti mengidentifikasi data. Artinya, peneliti ingin menemukan ciri penanda khas setiap data yang dikumpulkan. Berdasarkan ciri penanda khas tersebut, peneliti akan melakukan langkah analisis berikutnya. Kedua, atas dasar hasil identifikasi, peneliti akan membuat kategorisasi atau klasifikasi data berdasarkan penanda ciri khas yang sama. Atas dasar klasifikasi tersebut, peneliti akan melakukan interpretasi. Ketiga, peneliti menginterpretasi masing-masing kategori sebagai dasar untuk menjawab setiap rumusan masalah.

\section{HASIL KAJIAN DAN DISKUSI}

Di bawah ini disajikan temuan hasil kajian, baik hasil penelitian wujud bahasa nonverbal maupun makna pragmatiknya. Setelah penyajian hasil penelitian, artikel ini kemudian mengulas dalam bentuk hasl pembahasan. Secara berturut-turut disajikan sebagai berikut.

\subsection{Wujud Bahasa Nonverbal}

Wujud bahasa nonverbal dibedakan menjadi dua, yaitu bahasa nonverbal dinamis dan bahasa nonverbal statis $(\mathrm{Hu}, 2014)$. Gerakan nonverbal tidak selalu dapat disebut sebagai bahasa nonverbal. Gerakan nonverbal agar dapat disebut sebagai bahasa nonverbal harus memenuhi dua syarat, yaitu (a) gerakan itu harus dikaitkan dengan beberapa makna pragmatik, dan (b) hubungan gerakan itu harus dapat dipahami oleh mitra tutur (Krauss, Chen, \& Chawla, 1996). Oleh karena itu, bahasa nonverbal statis dapat mencakup di luar bagian tubuh. Kondisi strata sosial dalam masyarakat, jika dapat menyampaikan makna pragmatik dapat dikategorikan sebagai bahasa nonverbal.

Salah satu cara untuk mengenali jenis makna yang disampaikan oleh gerakan nonverbal dengan ucapan adalah dengan mengamati memori penutur. Kita tahu bahwa kata-kata yang diingat adalah maknanya, bukan sebagai rangkaian huruf atau fonemnya. Gerakan nonverbal seperti gerakan kaki ketika orang berjalan, lambaian tangan ketika orang berjalan, kerdipan mata ketika wajah kemasukan debu (Jawa: klilipen) bukanlah bahasa nonverbal. Gerakan nonverbal disebut bahasa nonverbal jika gerakan itu sengaja dimaksudkan untuk mengungkapkan makna pragmatik penutur.

Wujud bahasa nonverbal disampaikan melalui aspek nonlinguistik untuk penyampaian pesan yang mengacu pada beberapa cara selain penggunaan kata-kata. Bahasa nonverbal dapat dibedakan menjadi dua, yaitu dinamis dan statis (Hu, 2014) Bahasa nonverbal dinamis adalah bahasa tubuh beserta anggota tubuh disertai gerakannya, seperti kontak mata, gerakan anggota badan (misalnya ekspresi wajah, gerakan mata, gerakan kepala, gerakan tangan, gerakan badan), atau kombinasi yang satu dengan yang lain untuk mengungkapkan makna pragmatik penutur. Sementara itu, wujud bahasa nonverbal statis adalah (a) bagian tubuh yang mengandung makna pragmatik, seperti postur tubuh, raut muka, warna kulit, warna rambut, dan lain-lain yang dimiliki oleh penutur (Botting, 2005; Lapakko, 2007; Zhou, 2009), dan (b) status sosial, asal keturunan, dan persepsi terhadap kedudukan dalam masyarakat (Pranowo, 2018). 


\subsubsection{Wujud bahasa nonverbal dinamis}

Pemakaian bahasa nonverbal selalu dikaitkan dengan konteks pemakaian bahasa lisan dalam kehidupan seseorang. Misalnya, ketika seseorang bertutur "Jika itu kamu anggap lebih baik, ya silakan!" (konteks: penutur sambil memalingkan kepala dan melengos). Dengan bahasa nonverbal "memalingkan kepala dan melengos", mitra tutur menangkap makna pragmatik bahwa penutur tidak setuju dengan yang dimaksud mitra tutur. Oleh karena itu, mitra tutur kemudian mengatakan "Ya sudah, Pak, saya ikut Bapak saja". Artinya, konteks bahasa nonverbal lebih kuat maksudnya dibandingkan bahasa verbalnya.

Konteks adalah berbagai situasi di dalam atau di luar teks (seperti ko-teks, latar belakang sosial, latar belakang budaya) yang dapat mendukung penyampaian pesan penutur agar dapat dipahami oleh mitra tutur (Silvia \& Baricco, 2010). Wujud bahasa nonverbal sangat tergantung pada konteks yang menyertainya. Oleh karena itu, kadang-kadang wujud bahasa nonverbal sangat tergantung pada kemampuan menafsir penggunaan konteks oleh penutur maupun mitra tuturnya. Secara berturut-turut wujud bahasa nonverbal dinamis diuraikan sebagai berikut.

Bagi masyarakat Jawa pada khususnya dan Indonesia pada umumnya, anggukan kepala ketika bertutur dengan pendengar merupakan bahasa nonverbal untuk menyatakan persetujuan bagi pendengar terhadap makna pragmatik yang disampaikan oleh penutur. Misalnya, "Anda suka makan nangka?" Pertanyaan seperti itu, jika mitra tutur setuju dia akan menjawab dengan kata "ya" disertai anggukan kepala. Dapat pula tanpa mengatakan "ya" tetapi menganggukkan kepala juga dapat berarti setuju. Hal ini berbeda dengan gelengan kepala yang menyatakan penolakan mitra tutur terhadap makna pragmatik yang disampaikan oleh penutur. Dalam bahasa Jawa, "Kandhane mas Jarwo, jare kowe dhek wingi menyang Jakarta?" Pertanyaan seperti itu, jika mitra tutur menjawab dengan kata "ora" disertai gelengan kepala berarti penolakan. Jawaban atas pertanyaan tersebut dapat pula tanpa mengatakan kata "ora" tetapi kepala menggeleng juga dapat diartikan penolakan.

Kerlingan mata (mata melirik ke kiri atau ke kanan dengan posisi wajah tetap menatap ke objek yang didepannya) merupakan tanda memberi perhatian terhadap suatu objek (orang atau benda). Kerlingan seperti itu karena penutur sedang bertatap muka dengan mitra tutur, sementara itu ada objek lain yang tiba-tiba harus diperhatikan. Misalnya, penutur sedang berkomunikasi dengan mitra tutur tiba-tiba ada orang lewat. Tanpa mengesampingkan mitra tutur, penutur menyempatkan diri nelihat orang lewat yang ada di sampingnya. Sementara itu, kerdipan mata penutur memberi tanda atau isyarat terhadap mitra tutur bahwa penutur sepakat terhadap yang dimaksud mitra tutur atau penutur merasa tertarik terhadap mitra tutur.

Ekspresi wajah merupakan ungkapan perasaan penutur terhadap mitra tutur. Jika ekspresi wajah terkesan ceria, berarti penutur memberi tanda sedang berkenan di hati. Ekspresi wajah ceria itu terungkap ketika penutur baru saja membeli mobil baru, menerima hadiah, mendapati anaknya yang baru lulus ujian, atau baru memperoleh pekerjaan, dsb. Sebaliknya, jika ekspresi wajah penutur cemberut, berarti penutur sedang marah terhadap mitra tutur, atau kecewa terhadap suatu keadaan yang sebenarnya tidak diharapkan. Misalnya, penutur ingin agar mitra tutur menyelesaikan suatu pekerjaan yang ditugaskan kepadanya tetapi tidak dapat diselesaikan, atau penutur berharap agar mitra tutur tidak mengulangi kesalahan yang pernah dilakukan. Dengan berbagai kekecewaan seperti itu, penutur pasti cemberut. 
Gerakan bibir bagi seorang pria kadang-kadang berbeda dengan wanita. Bibir bawah seorang pria atau wanita yang dimajukan sambil menarik bibir atas menandakan bahwa mereka sedang kecewa dengan yang dimaksud mitra tutur. Sementara itu, jika bibir bawah wanita dikedepankan memberikan isyarat bahwa dia menandakan sedang mencibir mitra tutur. Namun, perspektif orang kadang-kadang berbeda. Ada gerakan bibir yang menandakan rasa ketertarikan pada lawan jenis, ada pula yang memberikan tanda kekecewaan dan perasaan sinis terhadap mitra tutur.

Bahasa nonverbal dinamis yang lain adalah gerakan tangan dan bagian-bagiannya. Berbagai gerakan tangan, seperti menjulurkan tangan ke depan dengan telapak tangan tengkurap sambil digerakan ke arah tubuh penutur bermakna pragmatik menyuruh mitra tutur mendekat, atau menjulurkan tangan ke depan telapak tangan tengkurap sambil digerakkan ke arah mitra tutur lebih keras berarti menyuruh mitra menjauh dari penutur. Gerakan tangan merangkul mitra tutur dengan penuh rasa senang menunjukkan bahwa penutur merasa merasa berkenan di hati dan memiliki hubungan dekat dengan mitra tutur.

Siku kanan dilipat ke arah kiri dan telapak tangan dirapatkan ke arah kiri menandakan penutur minta agar mitra tutur bergerak ke arah kiri penutur. Sebaliknya, jika siku tangan kiri dilipat ke arah kanan dan telapak tangan dirapatkan memberi isyarat agar mitra tutur bergerak ke arah kiri mitra tutur.

Gerakan jari juga dapat dipersepsi bermacam-macam. Jari telunjuk kanan atau kiri diacungkan ke atas dan ditempelkan ke bibir, penutur memberi isyarat agar mitra tutur diam dan tidak berbicara. Jika jari kelingking diluruskan ke bawah, sedangkan jari lain dilipat berarti memberikan isyarat bahwa sesuatu yang dimaksud penutur bermakna kecil. Jika jari telunjuk diarahkan ke depan sambil digerakkan ke kiri dan ke kanan sambal menatap mitra tutur bermakna agar mitra tutur tidak melakukan sesuatu seperti yang sedang dilakukan.

Ketika orang Jawa berjumpa dengan orang lain, biasa saling berjabat tangan untuk menandakan adanya hubungan kedekatan satu sama lain. Cara berjabat tangan dimulai dengan menjulurkan kedua tangan untuk menjabat telapak tangan mitra tutur dan kemudian dilepas dan kedua telapak tangan ditangkupkan lalu ditempelkan ke bibir atau ke dada sendiri sebagai ungkapan rasa persahabatan. Cara ini berbeda-beda setiap suku di Indonesia. Orang Sunda, ketika berjabat tangan terlebih dahulu menangkupkan kedua telapak tangan baru berjabat tangan.

Gerakan badan, meskipun tidak begitu produktif, sering dilakukan orang Jawa padaa khususnya dan orang Indonesia pada umumnya ketika berkomunikasi dengan orang lain. Gerakan menarik dada disertai kedua pundak dan telapak tangan lurus terbuka menandakan bahwa penutur memperlihatkan ketidaksetujuannya dengan yang dimaksud oleh mitra tutur. Jika penutur menggerakkan pantat ke kiri dan ke kanan ketika sedang menari menandakan bahwa penutur sedang ceria mengikuti alunan tari.

\subsubsection{Wujud bahasa nonverbal statis}

Wujud bahasa nonverbal lain, yaitu bahasa nonverbal statis (Hu, 2014). Hal ini berkaitan dengan tubuh dan bagian-bagiannya, benda-benda yang melekat pada tubuh, benda-benda yang dimiliki oleh seseorang, atau status sosial dalam masyarakat. Bahasa nonverbal statis juga dapat menyampaikan pesan tertentu kepada lawan bicara. Wujud bahasa nonverbal statis merupakan 
bagian badan atau barang yang tidak bergerak tetapi dapat mengungkapkan makna pragmatik penutur. Secara berturut-turut diuraikan sebagai berikut.

Postur tubuh bagi etnis Jawa memberikan pesan khusus pada lawan bicara. Bagi etnis Jawa, postur tubuh biasanya memiliki ketinggian sekitar $160 \mathrm{~cm}$. Namun, begitu melihat postur tubuh lebih dari $160 \mathrm{~cm}$ memberikan pesan sebagai orang yang jangkung, gagah dan perkasa (bagi laki-laki), sebaliknya postur tubuh tinggi besar (bagi wanita) memberikan pesan bahwa wanita tersebut berwibawa.

Batang hidung bagi etnis Jawa biasanya besar terepes atau "pesek". Oleh karena itu, etnis Jawa yang memiliki hidung mancung memberikan kesan sebagai orang yang cantik dan anggun bagi lawan bicara.

Bentuk pipi bagi etnis Jawa biasanya agak bundar. Namun, bagi etnis Jawa perempuan yang memiliki bentuk pipi "lesung pipit" (dhekik) ditafsirkan memberikan kesan sebagai wanita anggun dan cantik.

Bentuk bibir bagi etnis Jawa. Bibir wanita memiliki kesan khusus bagi laki-laki. Wanita yang memiliki bibir tipis memberikan kesan sebagai wanita yang cantik dan menawan, sebaliknya wanita yang memiliki bibir tebal dan lebar memberikan pesan sebagai wanita yang erotis.

Bentuk gigi tidak selalu nampak setiap saat, tetapi gigi memiliki pesan khusus bagi mitra tutur. Gigi wanita yang diidealkan oleh laki-laki Jawa adalah gigi yang larikan atas bawah runtut. Oleh karena itu, orang Jawa menyebutnya "untune miji timun" (giginya seperti biji mentimun). Di samping itu, warna gigi bagi pria maupun wanita yang dianggap ideal bagi orang Jawa adalah warna putih bersih. Gigi yang berwarna kekuning-kuningan dan berkarang memberikan kesan sebagai "gigi jorok".

Warna kulit bagi etnis Jawa yang dianggap menarik adalah warna kulit yang kekuningkuningan (kuning nemu giring “kuning seperti warna umbi 'temu giring'). Warna kuning nemu giring memberikan kesan sebagai warna kulit bersih. Sebaliknya, warna kulit yang cenderung putih pucat tidak disukai oleh etnis Jawa karena memberikan kesan sebagai orang tidak sehat. Begitu juga warna kulit yang cenderung hitam juga tidak disukai karena terkesan kotor.

Warna rambut. Jika ada orang Jawa yang berambut kemerah-merahan (sebagai warna alami) akan dikesankan sebagai orang yang tidak sehat. Warna rambut putih bagi orang Jawa dipersepsi sebagai orang yang sudah berusia lanjut. Orang muda yang sudah berambut putih dipersepsi sebagai orang "galak uwan" (rambut yang mudah beruban). Namun, di zaman modern ini, banyak orang muda atau tua rambutnya dicat warna-warni justru dipersepsi sebagai orang yang modis.

Bahasa nonverbal statis yang lain, yaitu perlengkapan tubuh yang menggambarkan status sosial dalam masyarakat, seperti pakaian, make up, perhiasan, asal keturunan, kedudukan dalam pekerjaan, dan kekayaan. Secara ringkas dapat diuraikan sebagai berikut. Seorang pria ketika mau bekerja selalu mengenakan pakaian serba rapi memberikan kesan bahwa pria itu selalu menjaga harkat dan martabat dirinya dalam penampilan dan ingin menghormati orang lain. Seorang pria Jawa ketika ada acara tradisional (misalnya upacara pernikahan) yang berperan sebagai panitia biasa memakai pakaian tradisional dalam setiap acara kedaerahan memberikan kesan bahwa dia ingin dipandang sebagai orang yang menghargai ciri khas kedaerahannya. Begitu juga, seorang pria ketika ada acara kedaerahan selalu mengenakan asesori ketika berpakaian daerah (keris, sabuk, selop, blangkon) menandakan bahwa dia ingin memberikan kesan sebagai orang yang selalu ingin melestarikan budaya daerah. 
Seorang wanita selalu mengenakan pakaian serba rapi, selalu berbedak, berlipstik, menyaput pipinya dengan warna merah merona menandakan agar lebih cantik. Sebaliknya, jika asesori yang dipakai terlalu berlebihan (gelang, subang besar, gelang kaki, kalung terlalu besar) memberikan kesan ingin pamer.

Di samping itu, masyarakat Jawa menggolongkan strata sosial sebagai bahasa nonverbal melalui beberapa cara. Pertama, masyarakat Jawa membedakan tingkat kepriyayian menjadi dua, yaitu "priyayi cilik" (priyayi kecil) dan "priyayi luhur". Priyayi cilik adalah orang kebanyakan yang memperoleh status priyayi karena mereka mendapat pangkat dalam pekerjaannya, gelar kesarjanaan, atau jabatan professor/ guru besar. Sebutan priyayi cilik juga diperuntukkan bagi mereka yang memiliki kedudukan dalam masyarakat, seperti ulama, kyai, pastur, pendeta.

Sementara itu, priyayi luhur adalah priyayi yang diperoleh karena keturunan keluarga raja (trah kusuma, rembesing madu). Mereka ditandai dengan pemberian nama sebagai gelar kebangsawanan dalam lingkungan keraton, seperti KGPH (Kanjeng Gusti Pangeran Hariya). KGT (Kanjeng Gusti Tumennggung), BRA (Bendara Raden Ayu), dsb. Mereka yang memiliki asal keturunan dari para bangsawan keraton ini selain disebut sebagai (trah kusuma, rembesing madu) juga disebut dengan istilah "darah biru".

Kedua, orang Jawa menggolongkan status sosial secara metaforis. Orang yang memiliki pendidikan tinggi biasa disebut esem Bupati (senyum Bupati). Orang yang termasuk kategori kelas atas biasanya tidak banyak bertutur untuk menyampaikan pesan tetapi memiliki pemikiran cerdas. Orang yang berkecerdasan tinggi selalu mengungkapkan makna pragmatik dengan "tersenyum" saja bukan dengan mengatakan secara verbal, baik untuk menyatakan kemarahan atau kegembiraan. Ungkapan esem Bupati seperti itu biasanya dinyatakan oleh orang yang memiliki kekuasaan besar dan sudah dipahami oleh anak buahnya secara nyata. Misalnya, penguasa tersebut kemudian tersenyum dan mengatakan "yang berani menghambat proyek nasional akan aku kirim ke "suka bumi" (akan dikubur di tanah) atau kukirim ke "Balik papan” (dimasukkan ke peti mati, dalam arti dibunuh).

Berikutnya adalah semu Mantri sebagai model komunikasi yang dinyatakan dengan bahasa verbal, dan didukung bahasa nonverbal. Itupun dinyatakan secara tidak langsung. Misalnya, seorang penutur berkomunikasi dengan orang lain mengatakan "wah durianmu bagus-bagus, itu jenis Musang King dari Malaysia ya, pak Tirta?”. Pertanyaan seperti itu diungkapkan oleh seorang Camat ketika mengunjungi kebun durian yang ditanam oleh warganya sebagai petani agro wisata. Pak Tirta sebagai petani tidak sekedar menjawab pertanyaan "ya" kepada pak Camat, tetapi "tanggap sasmita" (menangkap makna pragmatik di balik tuturan) bahwa "pak Camat tidak sekedar memuji tetapi ingin mencicipti duriannya". Pak Tirta menangkap makna pragmatik pak Camat, kemudian sore harinya Pak Tirta mengantarkan beberapa buah durian yang bagus-bagus ke rumah pak Camat sebagai ucapan terima kasih atas kunjungannya.

Sebaliknya, pak Camat juga "tanggap sasmita" bahwa pak Tirta sebagai petani pasti ingin beruntung. Oleh karena itu, pak Camat kemudian mengatakan bahwa "durian pak Tirta akan saya ikut sertakan dalam pameran agro wisata sebagai buah andalan yang akan diadakan di German bulan depan!'. Di samping itu, pak Camat memberikan uang sebagai ganti rugi atas durin yang sudah diberikan. Jawaban yang dinyatakan oleh pak Camat dan sekaligus memberikan uang merupakan komunikasi timbal balik dengan pola komunikasi "semu mantri". 
Di samping itu, ada komunikasi "dhupak bujang" yaitu status sosial yang dipakai untuk menyebut orang-orang kelas bawah yang latar belakang pendidikan dan ekonomi rendah. Status sosial kelas bawah ini ketika berkomunikasi selalu menggunakan bahasa verbal langsung agar paham makna pragmatik penutur. Misalnya, "Kamu baru datang, kamu mesti lapar, sana ke dapur minta makan sama bu likmu. Kalau makan yang kenyang ya?”.

Ada kategorisasi lain di dalam masyarakat. Komunikasi dengan bahasa nonverbal sebagai simbol status sosial kepriyayian etnis Jawa dapat berupa pangkat sebagai status kepriyayian seseorang yang diukur melalui kedudukan dalam pekerjaan. Setiap orang yang memperleh kedudukan tinggi di lingkungan pekerjaan (misalnya Bupati, Gubernur, anggota DPR), mereka dikategorikan sebagai priyayi. Berikutnya derajat merupakan status kepriyayian yang diperoleh karena masyarakat mengetahui bahwa dia memiliki kedudukan tinggi di lingkungan profesinya. Dan semat (kekayaan) yaitu sejumlah kekayaan yang dimiliki oleh seseorang di dalam masyarakat. Setiap orang yang memiliki harta kekayaan akan dipandang sebagai seorang priyayi di dalam masyarakat Jawa. Biasanya mereka yang memiliki pangkat dan derajat akan diikuti dengan memiliki semat (kekayaan).

Status sosial lain, kepriyayian Jawa diidentifikasi secara simbolis metaforis yang disebut "telu-teluning atunggal" berupa kukila, turangga, dan wanudya. Orang yang berstatus sosial menengah dengan kehidupan yang mapan biasanya memiliki burung yang suka berkicau. Dengan binatang piaraan berupa burung (kukila), menandakan dia sebagai priyayi. Namun, di zaman modern binatang piaraan tidak sesederhana itu, tetapi berkembang jauh lebih mewah, misalnya memelihara binatang yang tergolong langka, seperti burung Merak, burung Kaswari, burung Cocak Rawa, ayam Bekisar, burung Murai Batu dari Medan, dll. Simbol status sosial menengah atau atas yang lain adalah turangga (kuda tunggangan). Namun, turangga di zaman modern dimaknai sebagai kendaraan, seperti mobil dengan merek tertentu yang harganya bermilyar-milyar, pesawat pribadi, kapal pesiar, dan sejenisnya. Begitu juga simbol kepriyayian yang lain adalah wanudya. Simbol status sosial pada masyarakat Jawa menghargai hidup berpasangan dengan lawan jenis. Seorang pria yang berkedudukan tinggi atau kekayaan yang melimpah belum cukup kalau mereka belum memiliki istri (wanudya/ perempuan sebagai istri). Istri adalah pasangan hidup yang dapat menjanjikan generasi penerus.

Di samping itu, berkaitan dengan status sosial lain ada lima perkara yang dalam perjalanan hidup manusia tidak dapat diketahui secara pasti. Kelima perkara itu adalah siji, pesthi (satu, takdir); loro, jodho (dua, jodoh); telu, wahyu (tiga, anugerah), papat, kodrat (empat, nasib), dan lima, bandha (lima, kekayaan). Oleh karena itu, untuk memilih pasangan hidup yang sesuai juga perlu mempertimbangkan kualitas calon yang dijadikan kriteria, yaitu bobot, bibit, dan bèbèt. Masyarakat Jawa tidak cukup hanya memiliki harta dan tahta (kedudukan) kalau belum dilengkapi dengan wanudya (istri) (maaf, zaman dahulu masyarat Jawa cenderung bias jender. Seakan dunia yang memiliki adalah lelaki). Oleh karena itu, istri sering disebut sebagai kanca wingking (teman hidup dalam urusan domestik, seperti macak "bersolek", manak "beranak", dan masak).

Bobot adalah kriteria untuk menentukan calon istri berdasarkan kualitas diri, baik secara lahir maupun batin, seperti keimanan, pendidikan, pekerjaan, kecakapan dan perilaku si calon yang bersangkutan. Bibit adalah kriteria asal usul atau garis keturunan. Calon menantu harus jelas latar belakang kehidupannya, pendidikan seperti apa yang mereka peroleh. Hal ini perlu diperhitungkan karena watak yang dimiliki pasti akan menurun ke anak keturunan di kelak kemudian hari. Bèbèt merupakan status sosial yang berkaitan dengan harkat, martabat, prestige. 
Meskipun tidak boleh terobsesi, apa salahnya kalau status sosial sesorang juga menjadi bahan pertimbangan untuk menentukan calon menantu. Karena tidak bisa dipungkiri bahwa status sosial juga merupakan kebutuhan dasar manusia.

\subsection{Makna pragmatik Penggunaan Bahasa Nonverbal}

Bahasa nonverbal dapat digunakan untuk mengungkapkan beberapa makna pragmatik, yaitu (a) untuk mengulang kembali gagasan yang sudah dinyatakan secara verbal (repetissi), (b) untuk mengganti lambang-lambang verbal (substitusi), (c) untuk menolak pesan verbal atau memberikan makna lain terhadap pesan verbal (kontradiksi), (d) untuk melengkapi dan memperkaya makna pesan verbal (komplementary), (e) untuk menegaskan pesan verbal atau menggarisbawahinya (aksentuasi) tuturan (Foley, 2001; Knapp \& Hall, 2002). Secara rinci dapat dideskripsikan sebagai berikut.

\section{a. Makna pragmatik mengulang (repetisi)}

Bahasa nonverbal dapat digunakan sebagai makna pragmatik untuk mengulang tuturan verbal dalam komunkasi. Tuturan "Saya ingin agar tidak ada dusta di antara kita", sekali lagi, sambal mengacungkan jari tangan, penutur mengulangi ucapannya "Saya ingin agar tidak ada dusta diantara kita". Begitu juga, ketika penutur mengatakan "Sebagai saudara sebangsa dan setanah air, kita harus selalu bergandeng tangan dan berjabat tangan agar dapat membangun negeri ini menjadi bangsa yang maju". Dengan bertutur seperti itu, penutur menangkupkan telapak tangan kiri dan kanan sebagai tanda pengulangan "bergandeng tangan dan berjabat tangan". Makna pragmatik penutur dengan mengulangi bahasa verbal dengan menggunakan bahasa nonverbal seperti itu dapat ditangkap sebagai wujud pengulangan makna pragmatik penutur.

\section{b. Makna pragmatik substitusi}

Dengan substitusi, penutur mengungkapkan pesan ingin menggantikan tuturan bahasa verbal dengan bahasa nonverbal. Hal ini dimaksudkan agar tuturan tersebut dapat memberikan penegasan makna pragmatik penutur. Misalnya, "penutur menggoyang-goyangkan jari tangan ke kiri dan ke kanan" ketika mitra tutur bertanya balik "apakah saya boleh mengajukan satu pertanyaan lagi, Bu?" Penutur tidak menjawab secara verbal dengan kata "tidak boleh", tetapi hanya menggoyang-goyangkan jari ke kiri dan ke kanan saja. Contoh lain, ketika penutur sedang makan, kemudian mitra tutur mengatakan "terimakasih pak, selamat siang!" Penutur tidak menjawab dengan bahasa verbal "ya, silakan!" tetapi hanya melambaikan tangan sambal mengacungkan ibu jari kepada mitra tutur. Lambaian tangan dan acungan ibu jari tersebut dapat dimaknai sebagai “'ya, silakan!”.

\section{c. Makna pragmatik mempertentangkan}

Ketika penutur dengan mitra tutur sedang berkomunikasi, penutur mengatakan "apakah kondisi negara kita lebih buruk dari kondisi negara lain?" Mendengar tuturan seperti itu, mitra tutur tidak menjawab dengan bahasa verbal tetapi hanya "menangkat kedua pundak sambil tersenyum". Hal ini menandakan bahwa makna pragmatiknya tidak setuju dengan yang dikatakan oleh penutur. Begitu juga dengan ucapan "pendapat yang kamu katakan tadi bahwa 'harga bahan bangunan partisi lebih murah dari bahan dari kayu, itu memang praktis tetapi dari segi keindahan kan tidak indah ta', kata penutur". Mitra tutur tidak mau berdebat dengan penutur, kemudian hanya "tersenyum kecut" pada penutur. 


\section{d. Makna pragmatik melengkapi}

Tuturan nonverbal dapat pula bersifat komplementary (melengkapi). Artinya, bahasa nonverbal dapat melengkapi bahasa verbal sehingga makna pragmatik penutur dapat dipahami dengan jelas oleh mitra tutur. Ketika penutur sedang menjadi pembawa acara pementasan musik, dia mengatakan "marilah kita sambut penyanyi kita dengan tepuk tangan bersama", kemudian pembawa acara bertepuk tangan bersama penonton lain. Contoh lain, seperti tuturan penutur berkata "semua silakan diam dulu, saya akan melanjutkan bicara dulu" sambil menempelkan jari ke mulut. Jari yang menempel ke mulut dapat ditafsirkan sebagai gerakan nonverbal melengkapi.

\section{e. Makna pragmatik memberi penekanan}

Penutur dengan menggunakan bahasa nonverbal dapat bermakna pragmatik memberi tekanan pada tuturannya sehingga mitra tutur lebih mudah paham terhadap makna pragmatik penutur. Seorang penutur mengatakan "Saya tidak ingin ada lagi orang yang menghambat program pembangunan desa kita!" sambil mengacungkan jari ke atas sebagai penekanan tuturan. Dengan cara seperti itu, penutur memberi penekanan atas apa yang diungkapkan.

Di samping itu, ketika mitra tutur yang sepaham dan memiliki latar belakang budaya sama dengan penutur, biasanya tidak ada kesulitan untuk menangkap makna pragmatik yang diungkapkan oleh penutur. Namun, dalam kenyataannya setiap orang selalu berubah dan berkembang sehingga ada kemungkinan pendengar tidak selalu memahami makna pragmatik yang ingin diungkapkan oleh penutur. Misalnya, penutur mengatakan "seusiaku ini mestinya sudah memiliki karya lebih dari 50 judul buku". Tuturan itu hanya dapat dipahami dengan benar oleh mitra tutur apa bila dia mengenal penutur, seperti usia penutur, profesi penutur, jumlah karya yang sudah dihasilkan penutur, dsb. Dengan demikian, makna pragmatik yang ingin disampaikan adalah "sikap kerendahan hati penutur". Lain halnya, jika penutur mengatakan "memang seangkatan saya, yang punya prestasi bagus itu hanya saya". Ungkapan penutur nampak jelas bahwa tuturan itu memiliki makna pragmatik ingin menonjolkan diri terhadap mitra tutur. Dengan demikian, penutur memang sengaja ingin menonjolkn dirinya. Sikap seperti itu mengandung makna pragmatik "menyombongkan diri” terhadap mitra tutur.

Ada kalanya, penutur tidak bermaksud menojolkan diri di hadapan mitra tutur. Namun, kadang-kadang mitra tutur memiliki sensitifitas yang terlalu peka sehingga tuturan yang dimaksud oleh penutur dianggap biasa saja tetapi dipahami oleh mitra tutur dengan makna pragmatik yang lain. Misalnya, "Anda kebetulan orang yang tidak beruntung, tinggal satu langkah saja terpaksa tidak lolos seleksi". Melalui tuturan tersebut, penutur ingin menunjukkan rasa empati kepada mitra tutur. Namun, karena mitra tutur sedang dirundung kecewa berat atas kegagalannya, mitra tutur memahami makna pragmatik penutur sebagai "ejekan".

Dari berbagai data di atas, komunikasi bahasa verbal yang didukung dengan bahasa nonverbal ternyata tidak selalu mudah dipahami mitra tutur. Bahkan, kadang-kadang makna pragmatik penutur dipahami secara bertolak belakang oleh mitra tutur. Untuk mengurangi kesalahpahaman antara penutur dengan mitra tutur, beberapa pengetahuan lain perlu saling dipahami secara bersama-sama. Secara ringkas, hal tersebut diuraikan sebagai berikut. 
a. Membangun dasar pemahaman yang sama (common ground)

Pertanyaan seorang suami "Sudah jam berapa, ya Bu?" dan istri yang ditanya kemudian menjawab "Kereta api belum lewat, tu Pak!", penanya kemudian mengatakan "O, ya sudah. Berarti masih ada waktu" (Pranowo, 2009). Komunikasi antara suami dan istri seperti itu nampak tidak padu secara sintaktis (tidak kohesif). Namun, kenyataannya sang suami merasa sudah cukup mendapat informasi dari jawaban istrinya. Buktinya, suami tidak protes apa-apa tetapi justru mengatakan " $O$, ya sudah berarti masih ada waktu". Artinya, komunikasi tersebut padu secara semantik (kohern). Hal tersebut terjadi karena suami dengan istrinya sama-sama memiliki dasar pemahaman yang sama (common ground) mengenai soal waktu. Dasar pemahaman yang sama yang dimaksud adalah sama-sama memiliki pemahaman mengenai konteks. Tuturan suami-istri di atas menjadi kohern karena keduanya sama-sama memiliki dasar pemahaman yang sama (common ground) bahwa pada jam tertentu kereta api pasti lewat. Sementara itu, ketika suaminya bertanya "Jam berapa?", si istri tidak perlu pergi melihat arloji penunjuk waktu yang ada di kamar tetapi dengan spontan mengatakan "Kereta api belum lewat, tu Pak". Inilah yang dimaksud sebagai konteks dalam bidang pragmatik.

b. Mengenali latar belakang budaya mitra tutur

Tuturan yang biasa diungkapkan oleh anak-anak Indonesia bagian timur. Mereka sering memotong-motong kata atau sering kita mendengar istilah "delisi" penghilangan sebagian suku kata, seperti "Sapi main bola, Mah". Jika mitra tutur hanya memahami secara linguistik, tentu tidak dapat menangkap makna pragmatik penutur. Bagaimana mungkin "Sapi main bola". Padahal, penutur ketika berujar memotong kata "saya" menjadi "Sa-" dan "pigi/pergi" menjadi "pi-"sehingga "Saya pergi" hanya diucapkan menjadi "Sapi". Bagi penutur yang sama-sama orang Indonesia Timur, mendengar ujaran seperti itu dapat dengan mudah memahami makna pragmatik penutur. Penutur tidak ingin mengatakan bahwa "Lembu bermain bola" tetapi minta izin kepada Ibunya untuk pergi bermain bola. Hal demikian hanya dapat dipahami jika penutur dan mitra tutur sama-sama memahami latar belakang budaya bertutur sehari-hari dalam masyarakat. Mereka memiliki latar belakang budaya yang berbeda-beda tetapi saling dipahami oleh komunitasnya. Hal-hal seperti itulah yang disebut konteks budaya.

c. Menangkap asumsi penutur terhadap mitra tutur

Sebagai awal membangun asumsi dalam berkomunikasi, penutur dapat melakukan berbagai cara untuk menjajagi mitra tutur agar dapat menemukan persepsi yang sama. Misalnya, ketika berjumpa dengan seseorang di dalam kereta api atau pesawat, mereka duduk berdampingan. Kalau duduk berdampingan tetapi tidak berkomunikasi juga aneh. Sebagai awal pembuka percakapan, mereka dapat saling bertanya siapa namanya, tujuan kepergiannya ke mana, profesinya apa, dsb. Semakin lama, semakin banyak informasi yang dapat digali dari mitra tutur. Inilah cara penutur membangun asumsi terhadap mitra tutur.

d. Sama-sama mengenali knowledge of the world (pengetahuan umum)

Ketika penutur berkomunikasi dengan mitra tutur, dan mereka memiliki knowledge of the world yang sama, berarti keduanya memiliki dasar pemahaman yang sama mengenai topik yang dibicarakan sehingga mereka akan dapat berkomunikasi secara lancar. Latar belakang pengetahuan budaya dapat menjadi salah satu dasar dapat atau tidaknya komunikasi berjalan lancar. Bagi orang yang memiliki latar belakang pengetahuan budaya sama, kecenderungan 
komunikasi dapat berjalan lancar lebih besar. Sebaliknya, jika orang yang terlibat dalam komunikasi berbeda latar belakang pengetahuan budayanya, ada kemungkinan dapat salah paham ketika mereka berkomunikasi. Jika aspek-aspek di atas dimiliki oleh penutur dan mitra tutur, komunikasi akan berjalan dengan baik dan pemahaman mitra tutur terhadap tuturan penutur akan lebih mudah. Hal ini akan mudah dilakukan apa bila mitra tutur memiliki pengetahuan umum yang sama dengan penutur, memiliki latar belakang budaya yang sama dengan penutur, memiliki sejumlah asumsi yang sudah dipahami oleh mitra tutur, dan memiiki knowledge of the world yang sama dengan penutur.

\section{e. Memahami ungkapan metaforis penutur}

Seperti strata sosial masyarakat Jawa, ungkapan metaforis dapat diketahui melalui perbandingan langsung yang menggunakan perlambang. Ungkapan metaforis tersebut dapat berupa (1) tingkat kepriyayian dalam masyarakat diungkapkan secara metaforis dengan menggunakan lantai rumah joglo dengan istilah esem Bupati, semu Mantri, dan dhupak Bujang, (2) untuk mengidentifikasi asal darah keturunan diungkapkan secara metaforis dengan istiah bobot, bibit, dan bebet, (3) untuk membedakan kedudukan sosial dalam masyarakat diungkapkan secara metaforis yang diidentifikasi melalui kepemilikan, yaitu kukila (burung berkicau), turangga (kuda tunggangan), dan wanudya (istri).

\section{f. Memiliki penguasaan kosa kata yang cukup}

Penguasaan kosa kata yang cukup, baik penutur maupun mitra tutur akan sangat mudah memilih kata yang harus digunakan dan akan sangat membantu mitra tutur memahami makna pragmatik penutur. Penguasaan kosa kata, terutama yang berkaitan dengan kesinoniman (seperti kata mati, meninggal, tewas, gugur, wafat; besar, raksasa, akbar) selalu digunakan untuk tuturan tertentu yang disertai dengan bahasa nonverbal; kehomoniman, seperti kata "bisa" dapat berarti "racun pada binatang" dan dapat pula bermakna "mampu" atau "dapat". Hal-hal lain yang berkaitan dengan penguasaan kosa kata, seperti pemahaman terhadap gaya bahasa sangat penting dalam komunikasi.

\subsection{Pembahasan}

Gerakan nonverbal tidak semua dapat disebut sebagai bahasa nonverbal. Hanya gerakan nonverbal yang sengaja dimaksud untuk mengungkapkan makna pragmatik penutur dapat diseebut sebagai bahasa nonverbal. Hal ini sejalan dengan yang dimaksud oleh Krauss \& Chawla bahwa bahasa nonverbal harus memenuhi dua syarat, yaitu (a) gerakan itu harus dikaitkan dengan beberapa makna semantik, dan (b) hubungan gerakan itu harus dapat dipahami oleh mitra tutur (Krauss dkk., 1996).

Dari sekian banyak pengertian, bahasa nonverbal dapat dibedakan menjadi dua, yaitu bahasa nonverbal dinamis dan bahasa nonverbal statis (Hu, 2014). Bahasa nonverbal dinamis selalu mengacu pada gerakan tubuh, gerakan bagian tubuh, dan gerakan anggota tubuh. Sedangkan bahasa nonverbal statis dapat dibedakan menjadi beberapa hal, seperti (a) postur tubuh, anggota tubuh, warna kulit dan lain-lain yang tidak digerakkan tetapi dapat mengungkapkan makna pragmatik tertentu bagi penuturnya, (b) status sosial dalam masyarakat. Status sosial dalam masyarakat meliputi (i) tingkat keluhuran, ada priyayi cilik dan priyayi luhur ("darah biru"), (ii) ungkapan metaforis atas suatu jenjang pendidikan meliputi esem Bupat, 
semu Mantri, dan dhupak Bujang, (iii) kategorisasi status sosial berkaitan dengan kedudukan meliputi pangkat, derajat, semat, (iv) tingkat kepriyayian meliputi kukila, turangga, dan wanudya, (v) bahasa nonverbal statis sebagai keyakinan dalam kehidupan orang Jawa, meliputi siji pesthi (satu takdir), loro jodho (dua, jodoh), telu, wahyu (tiga, anugerah), papat kodrat (empat, kodrat), dan lima, bandha (lima, kekayaan), dan (vi) bahasa nonverbal lain, meskipun sudah mulai ditinggalkan adalah stigma istri sebgai "kanca wingking" (teman belakang) yang tugasnya berkaitan dengan urusan domestic, yaitu seperti mac "bersolek", manak "beranak", dan masak (Pranowo, 2018).

Jika dikaitkan dengan teori-teori bahasa nonverbal yang dikemukakan oleh para ahli pragmatik maupun ahli komunikasi, kajian bahasa nonverbal masih harus ditelusur lebih jauh lagi. Terutama, bahasa nonverbal statis yang berkaitan dengan status social. Di samping itu, beberapa aspek yang perlu diperhatikan dan belum banyak dikaji oleh para ahli adalah aspek bahasa nonverbal yang berdiri sendiri, seperti (a) bagi anak kecil yang sedang dalam proses pemerolehan bahasa, (b) bahasa nonverbal orang dewasa yang sama-sama tidak menguasai bahasa verbal mereka, (c) bahasa nonverbal yang memiliki perbedaan latar belakang budaya.

\section{KESIMPULAN}

Berdasarkan uraian di atas dapat disimpulkan beberapa hal sebagai berikut. Pertama, bahasa nonverbal adalah bahasa yang secara sengaja digunakan oleh penutur untuk mengungkapkan makna pragmatik tertentu. Tidak semua gerakan nonverbal dapat disebut sebagai bahasa nonverbal.

Kedua, wujud bahasa nonverbal dapat dibedakan menjadi dua, yaitu dinamis dan statis. Wujud bahasa nonverbal dinamis adalah bagian tubuh atau anggota tubuh yang digerakkan dan dapat mendukung makna pragmatik penutur. Sebaliknya, bahasa nonverbal statis adalah bgian tubuh atau anggota tubuh, strata sosial dalam masyarakat tertentu yang dapat diinterpretasi sebagai makna pragmatik dalam komunkasi. Meskipun demikian, bahasa nonverbal statis masih perlu dikaji lebih dalam terutama yang berkaitan dengan status social masyarakat Jawa.

Ketiga, makna pragmatik yang ingin disampaikan melalui bahasa nonverbal meliputi cara yang digunakan oleh penutur kepada mitra tutur. Makna pragmatik dapat berupa sikap penutur terhadap mitra tutur ketika mereka berkomunikasi.

\section{CATATAN}

Penulis berterima kasih kepada mitra bebestari yang telah memberikan masukan yang berharga untuk meningkatkan kualitas makalah ini.

\section{REFERENSI}

Argyle, M. (1972). Nonverbal communication in human social interaction. In. R. A. Hindie, Nonverbal communication. Oxford: Cambridge University Press.

Barry, B. E. (2011). Student nonverbal communication in the classroom. American Society for Engineering Education, 1-14. 
Bonaccio, S., O'Reilly, J., O'Sullivan, S. L., \& Chiocchio, F. (2016). Nonverbal behavior and communication in the workplace. Journal of Management. https://doi.org/10.1177/0149206315621146

Botting, N. (2005). Non-verbal cognitive development and language impairment. Journal of Child Psychology and Psychiatry and Allied Disciplines. https://doi.org/10.1111/j.14697610.2004.00355.x

Foley, W. A. (2001). Anthropological linguistics. Massachusetts: Blackwell Publisher Inc.

$\mathrm{Hu}, \quad \mathrm{X}$. (2014). Context: From static to dynamic. 2(2), 127-133. https://doi.org/10.11648/j.ij11.20140202.21

Knapp, M. L., \& Hall, J. A. (2002). Nonverbal communication in human interaction. Crawfordsville: Thomson Learning.

Krauss, R. M., Chen, Y., \& Chawla, P. (1996). Nonverbal behavior and nonverbal communication: What do conversational hand gestures tell us? Advances in experimental social psychology. https://doi.org/10.1016/S0065-2601(08)60241-5

Lapakko, D., \& Lapakko, D. (2007). Communication is $93 \%$ nonverbal: An urban legend proliferates communication is $93 \%$ nonverbal: An urban legend proliferates. 34, 7-19.

Levinson, S. C. (n.d.). Pragmatics. Cambridge: Cambridge University Press.

Mehrabian, A. (2017). Nonverbal communication (e-book). New York: Routledge.

Miller, D. (2011). Miller (1983) revisited: A reflection on EO research and some suggestions for the future. Entrepreneurship: Theory and Practice. https://doi.org/10.1111/j.15406520.2011.00457.x

Pranowo, P. (2018). Basa Jawa krama alus lan santun.

Rahardi, K. (2009). Sosiopragmatik. Yogyakarta: PT Gelora Aksara Pratama.

Silvia, D., \& Baricco, L. De. (2010). Presión arterial. Silvia Luluaga de Baricco.

Song, L. (2011). The role of context in discourse analysis. Journal of Language Teaching and Research. https://doi.org/10.4304/j1tr.1.6.876-879

Spradley, J. (1979). Interviewing an informant. In The Ethnographic Interview.

Spradley, J. (1998). The ethnographic interview (from Spradley, 1979). In Introduction to Qualitative Methods.

Spradley, J. P., Elizabeth, M. Z., \& Amirudin. (1997). Metode etnografi. Yogyakarta: Tiara Wacana.

Wang, H. (2014). Nonverbal communication and the effect on interpersonal communication. Asian Social Science, 5(11), 155-159. https://doi.org/10.5539/ass.v5n11p155

Zhou, H. (2009). Body language in business negotiation. International Journal of Business and Management, 3(2), 90-96. https://doi.org/10.5539/ijbm.v3n2p90 